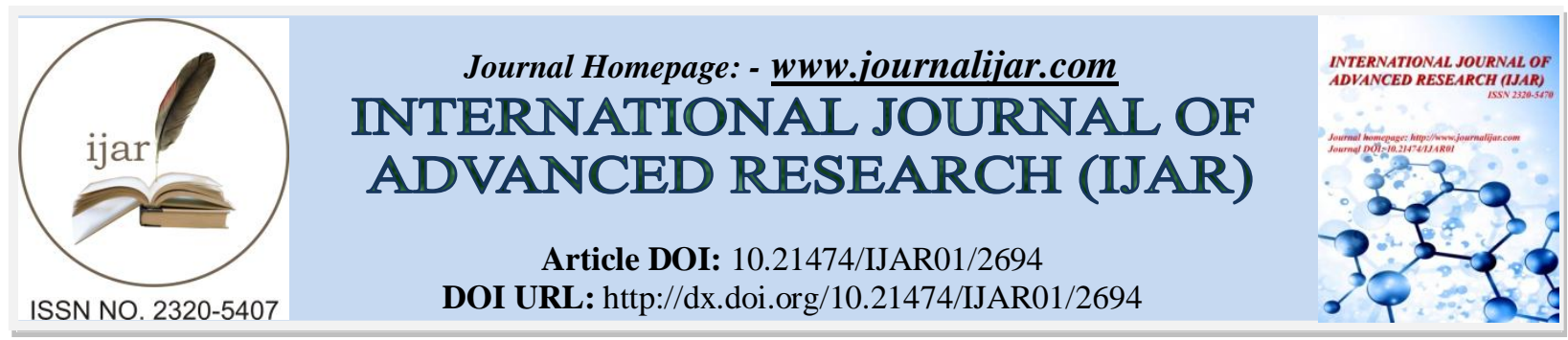

RESEARCH ARTICLE

\title{
AEROALLERGEN SKIN PRICK TEST REACTIVITY LACKS SEASONAL VARIATION IN RIYADH REGION.
}

Zahid Shakoor, Fatima Alanazi, Nory Aldosari and Abdullah Alangari.

Department of Pathology, College of Medicine, King Saud University, Riyadh, Kingdom of Saudi Arabia.

\section{Manuscript Info}

Manuscript History

Received: 31 October 2016

Final Accepted: 01 December 2016

Published: December 2016

Key words:-

Aeroallergen, skin prick test, airway

allergy, seasonal.

\section{Abstract}

Background:- Exposure to aeroallergens varies in different seasons and correlates with increased frequency of sensitized individuals seeking medical aid.

Objectives:- Based on skin prick reactivity during each calendar month of the year the reactivity pattern of aeroallergens was assessed.

Methods:- This was a retrospective analysis of data of 238 patients (165 female and 73 male; mean age $26+11$ years) with airway allergy undergoing skin prick testing between 2014 and 2016 at King Khalid University Hospital, Riyadh. A wheal diameter measuring $3 \mathrm{~mm}$ or more was considered as a positive reaction.

Results:- Among the individuals tested there were $98(41.1 \%)$ patients with asthma, $115(48.3 \%)$ had rhinitis and 25 (10.5\%) were suffering from hay fever. The most frequently reacting indoor aeroallergen was cat in $120(50.2 \%)$ patients followed by Dermatophagodies farinae in 78 (32.6\%), Dermatophagodies pteronyssinus in $67(28 \%)$ and Aspirgillus in 57 (23.8\%). Among the outdoor aeroallergens cynodon dactylon reactivity was observed in 90 (37.6\%) patients followed by salsola kali in $86(36.2 \%)$ and lolium perenne in 83 (34.7\%). Reactivity against the cat allergen was consistently higher than the house dust mite allergens peaking in October until the month of March. Reactivity pattern of salsola kali, cynodon dactylon and lolium perenne was almost similar and remained higher than the other pollens between the months from September to May. Data for the months of July and August were not available.

Conclusion:- Skin prick test reactivity against aeroallergens was not only high in Riyadh region but was also devoid of seasonal variations.

\section{Introduction:-}

Aeroallergen exposure triggers a robust specific $\operatorname{IgE}$ antibody response among sensitized individuals resulting in increased serum level of specific IgE antibody and skin test reactivity (1).Higher pollen counts in the environment during specific pollen season are known for their ability to induce allergy symptoms among sensitized individual most likely due to increased production of specific IgE. Elevation of ragweed specific IgE antibodies among ragweed sensitized airway allergy patients during and following ragweed pollination season points to a direct relationship between the environmental allergen exposure and serum levels of specific IgE antibodies (2).Moreover among tree pollen sensitized individuals the skin test reactivity not only correlates with tree pollen counts but the 
size of the allergen induced wheal also increases during the pollen season (3). The reduction in nasal flow values observed among children with seasonal allergic rhinitis during the pollen season may possibly be related to ambient allergen load (4). Patients suffering from asthma are known to exhibit seasonal variation in hospital visits seeking medical aid for acute exacerbations of asthma related symptoms (5). These seasonal variations in hospital visits have been shown to exhibit a strong positive correlation with pollen counts (6). The concentration of house dust mite (HDM) allergen is traditionally believed to be prevalent throughout the year has also been reported to exhibit seasonal variations $(7,8)$. HDM allergen concentration peaks during the fall in Korea and it is associated with concurrent elevation of HDM allergen specific $\operatorname{IgE}$ in the sera of sensitized individuals $(9,10)$. It is therefore quite conceivable that exaggeration of clinical signs and symptoms of allergy in different seasons is consequent to increased production of specific IgE due to higher exposure to allergen (11). Riyadh region is a desert terrain, less humid and extended summer time with temperatures ranging between $40 \mathrm{oC}$ to $50 \mathrm{oC}$ offers a unique opportunity to investigate seasonal variations in aeroallergen exposure. This study was performed to assess the seasonal variations in skin prick test reactivity in Riyadh region.

\section{Patients and methods:-}

This retrospective study was performed to extract data for skin test reactivity of all patients with airway allergy between 2014 and 2016 at King Khalid University Hospital, Riyadh. The hospital is a tertiary care hospital catering for patients from Riyadh region. During the study period a total of 321 patients underwent skin prick testing with $238(74.1 \%)$ yielding positive results reacting to either one or more allergens. This group of patients included 165 (69.3\%) females and $73(30.7 \%)$ male patients with the mean age of $26+11$ years. There were $98(41.1 \%)$ patients with asthma, $115(48.3 \%)$ had rhinitis and $25(10.5 \%)$ were suffering from hay fever. Patients were advised to discontinue treatment with oral antihistamines at least one week prior to being skin tested. Patients who could not stop antihistamine therapy because of the severity of the symptoms, those on long term steroid therapy and pregnant women were not offered skin prick test.Table 1 contains the list of indoor and outdoor aeroallergen panel used for skin prick test. A positive (histamine dihydrogen phosphate $1 \mathrm{mg} / \mathrm{ml}$ ) and a negative (normal saline) controls were also included for each assessment. Skin prick test was performed by placing a drop of each allergen including the controls on the skin of forearm and the underlying skin was nicked by a fine lancet. The excess amount of each allergen was removed by filter paper and the interpretation of results was performed after 15 minutes by measuring the diameter of the wheal. A skin prick test was considered positive if the wheal diameter was either equal to or more than $3 \mathrm{~mm}$.

\section{Statistical analysis:-}

Data were recorded in Excel spreadsheet and were analyzed by SPSS computer software version Categorical data were summarized as numbers and percentages and numeric data were summarized as mean and standard deviation.

\section{Results:-}

Figure 1 shows data for the common indoor allergen sensitization based on skin prick test reactivity. Out of the total $120(50.2 \%)$ patients were sensitized against cat allergen followed by $78(32.6 \%)$ against Dermatophagodies farinae, 67 (28\%) against Dermatophagodies pteronyssinus, 57 (23.8\%) against Aspirgillus and 42 (17.5\%) patients were sensitized against Alternateria alternata. Among the outdoor allergens the most frequently observed reactivity was against Cynodon dactylon among 90 (37.6\%) patients followed by Salsola kali in 86 (36.2\%), Lolium perenne in 83 (34.7\%), Amaranthus retroflexus in 71 (23.8\%), Artimesia vulgaris in 57 (23.8\%) and dates in 48 (20\%) patients (Fig. 2). Interpretation of the seasonal variation was performed by categorization of skin prick test reactivity on monthly basis for each allergen. Figure 3 shows data for number of positive skin prick tests for common indoor allergens in each month of the year. Cat allergen reactivity was consistently higher than house dust mite and peaking in the month of October through to the month of March. House dust mite reactivity was higher than the cat allergen reactivity in the month of June. Skin prick test reactivity against the pollens was frequently observed against Salsola kali, cynodondactylon, loliumperenne and amaranthusretroflexus (Fig. 4). Reactivity pattern ofSalsola kali, cynodondactylon andloliumperenne was almost similar and remained higher than other pollens between the months from September to May. Amaranthus skin reactivity peaked in the month of December and declined in May. Data for the aeroallergen reactivity were not available for the months of July and August. 


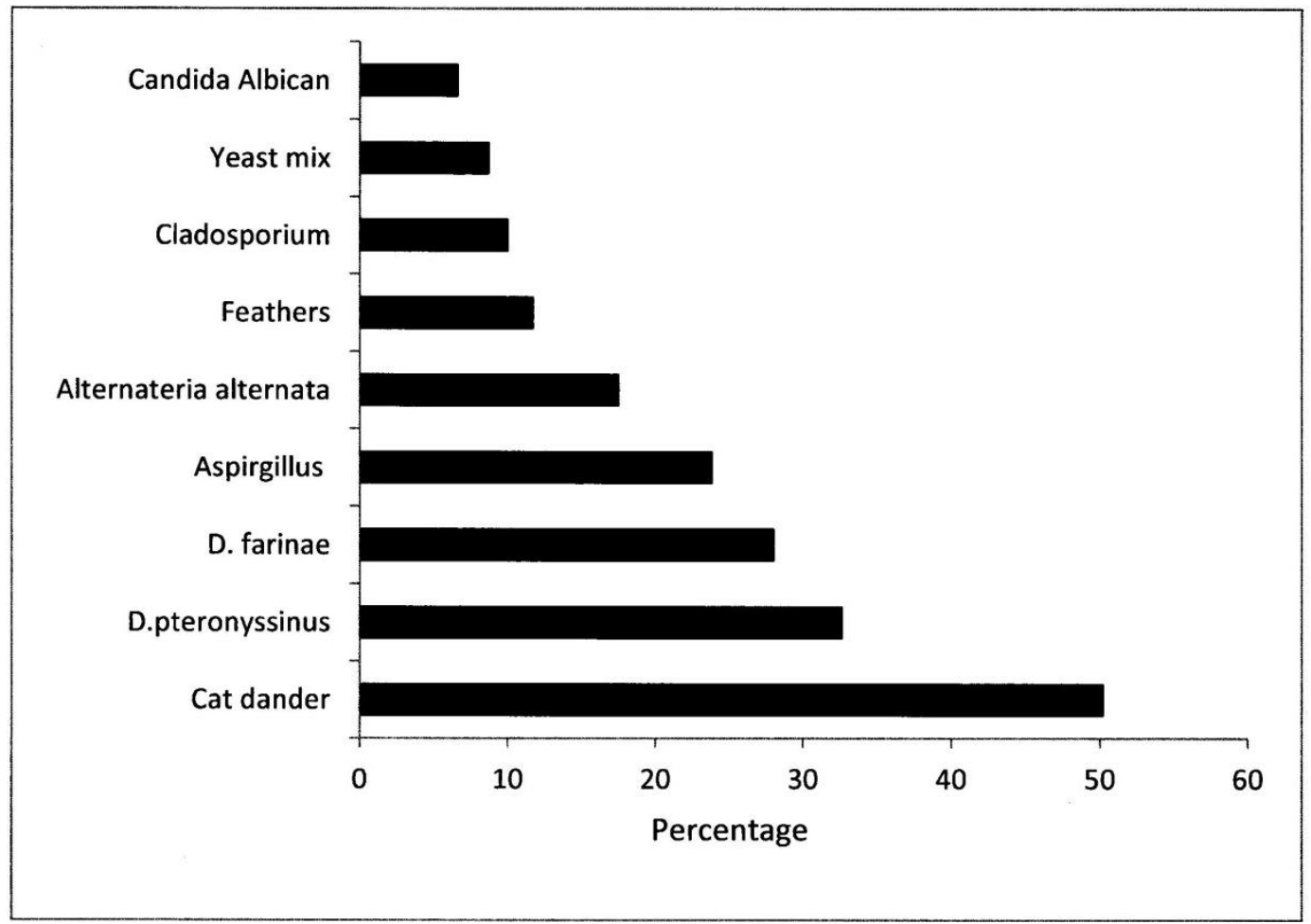

Fig.1:-

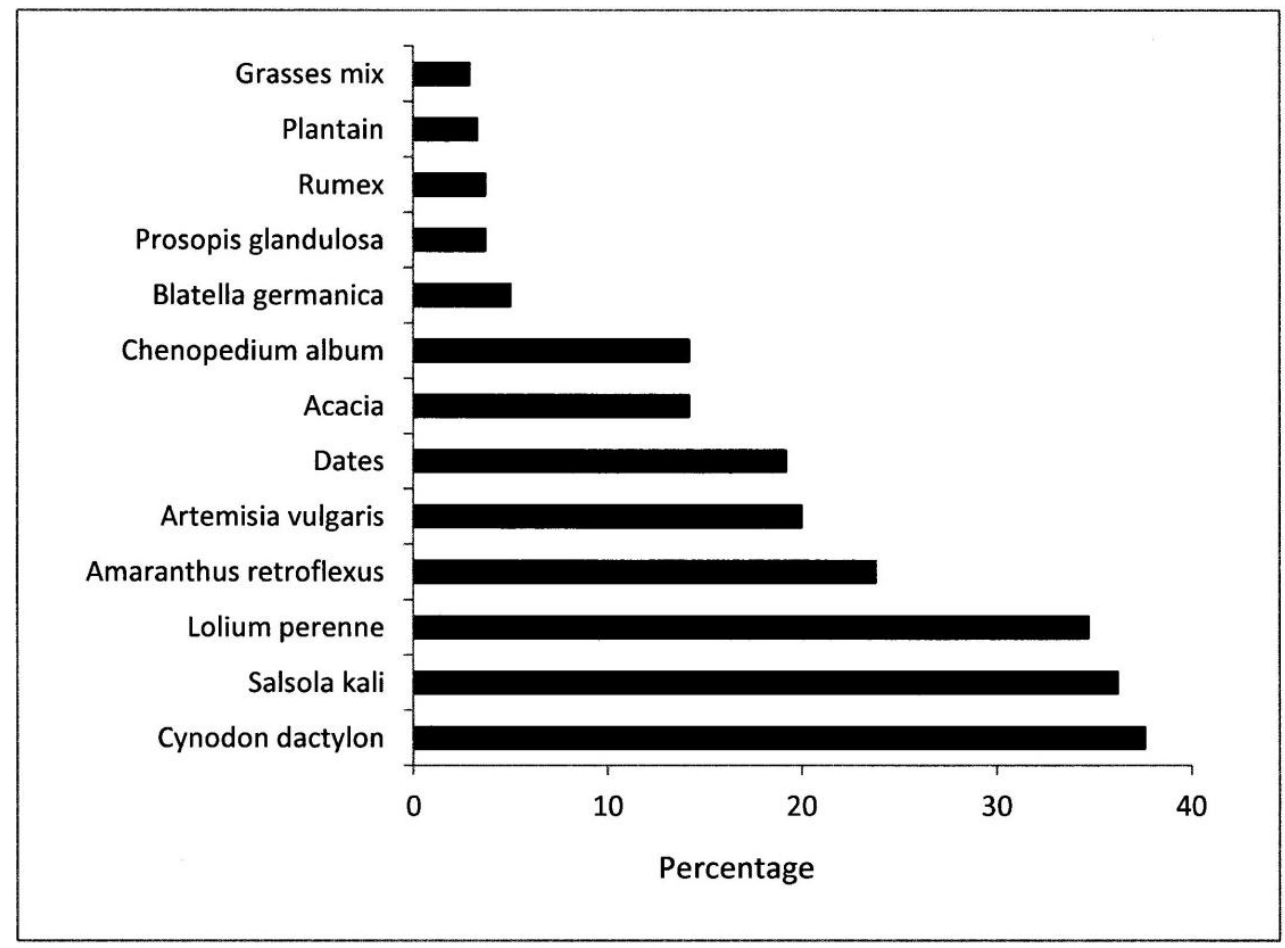

Fig. 2:- 


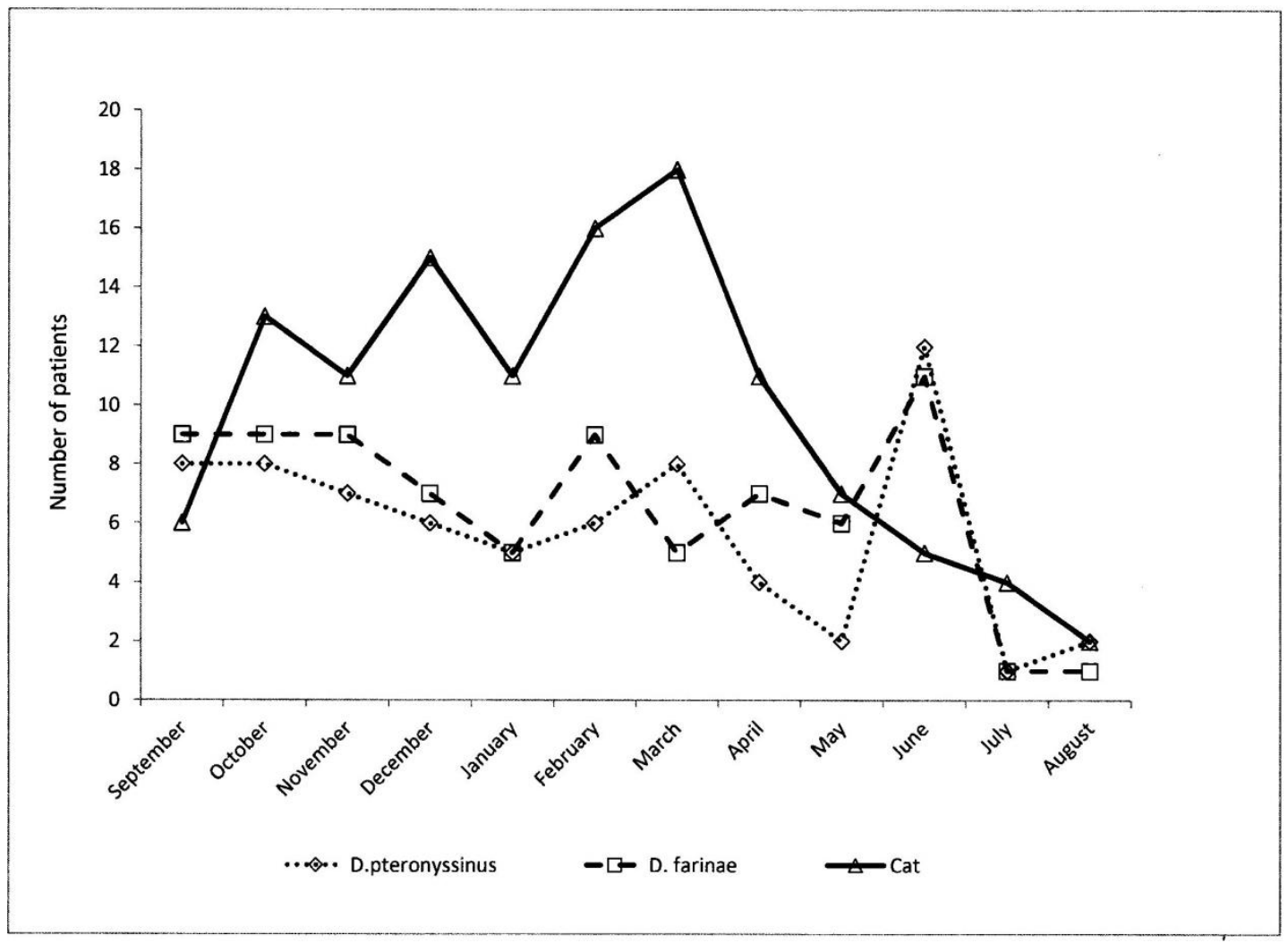

Fig 3:-

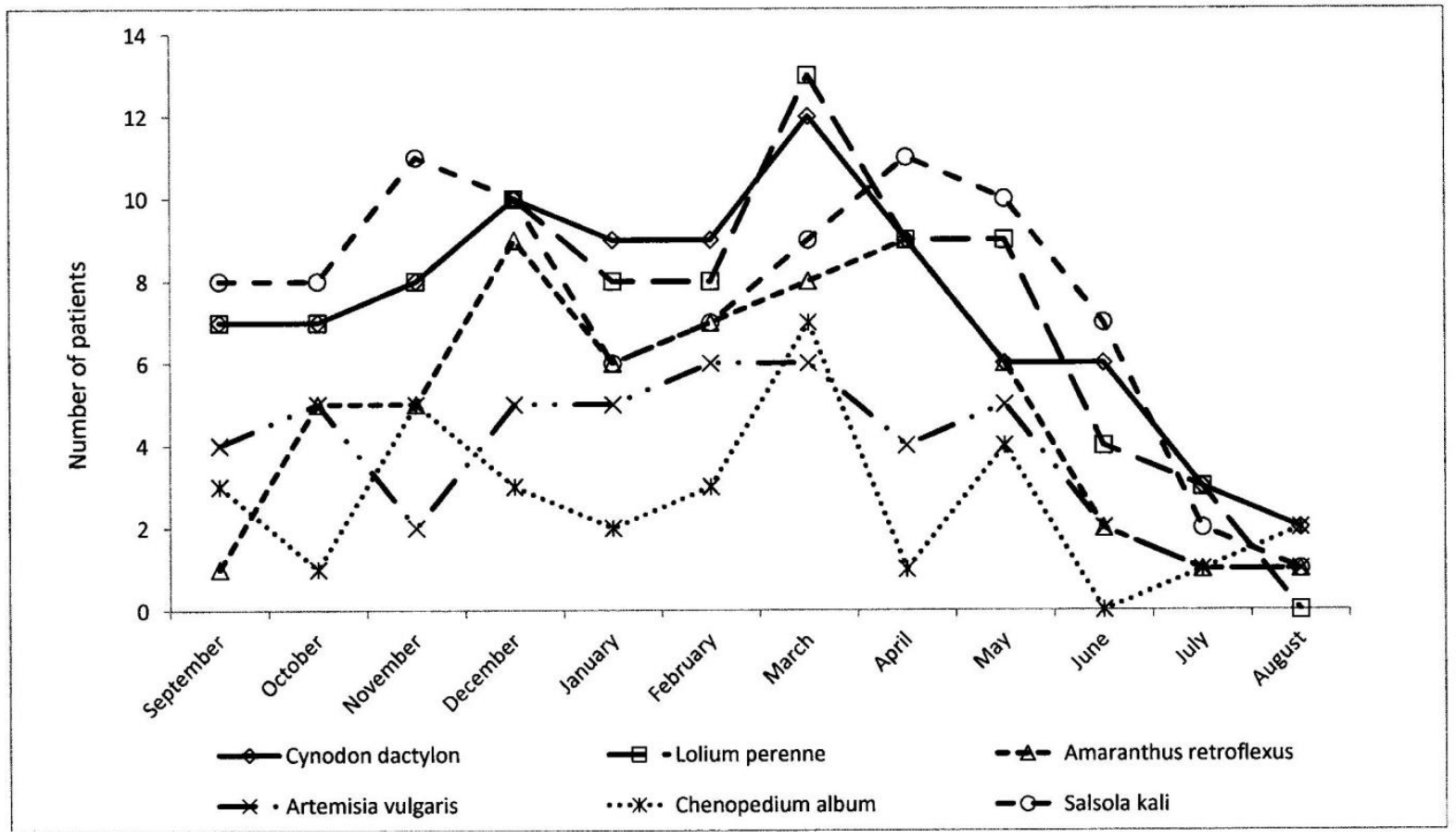

Fig 4:- 


\begin{tabular}{|c|c|}
\hline Allergen & Concentration \\
\hline Mixed Grasses & $1: 20 \mathrm{w} / \mathrm{v}$ \\
\hline Mixed Trees & $1: 20 \mathrm{w} / \mathrm{v}$ \\
\hline Red Sorrel & $1: 20 \mathrm{w} / \mathrm{v}$ \\
\hline Plantigo lanceolate & $1: 20 \mathrm{w} / \mathrm{v}$ \\
\hline Mugwort common & $1: 20 \mathrm{w} / \mathrm{v}$ \\
\hline Cynodon dactylon & $1: 10 \mathrm{w} / \mathrm{v}$ \\
\hline Acacia & $1: 20 \mathrm{w} / \mathrm{v}$ \\
\hline Lolium multiflorum & $1: 10 \mathrm{w} / \mathrm{v}$ \\
\hline Chenopodium album & $1: 20 \mathrm{w} / \mathrm{v}$ \\
\hline Alternaria & $1: 20 \mathrm{w} / \mathrm{v}$ \\
\hline Dermatophagodies pteronyssinus & $10,000 \mathrm{IU} / \mathrm{ml}$ \\
\hline Dermatophagoides farinae & $10,000 \mathrm{IU} / \mathrm{ml}$ \\
\hline Cockroach & $1: 100 \mathrm{w} / \mathrm{v}$ \\
\hline Cat & $1: 10 \mathrm{w} / \mathrm{v}$ \\
\hline Horse Epithelia & $1: 10 \mathrm{w} / \mathrm{v}$ \\
\hline Sheep Hair & $1: 10 \mathrm{w} / \mathrm{v}$ \\
\hline Goat Hair & $1: 20 \mathrm{w} / \mathrm{v}$ \\
\hline Camel Hair & $1: 20 \mathrm{w} / \mathrm{v}$ \\
\hline Aspergillus mix & $1: 20 \mathrm{w} / \mathrm{v}$ \\
\hline Cladosporium & $1: 20 \mathrm{w} / \mathrm{v}$ \\
\hline Candida albicans & $1: 20 \mathrm{w} / \mathrm{v}$ \\
\hline Penicillium notatum & $1: 20 \mathrm{w} / \mathrm{v}$ \\
\hline
\end{tabular}

\section{Discussion:-}

This study revealed that the skin reactivity toindoor allergens such as cat and house dust mite allergens and outdoor allergens including cynodondactylon, salsola kali and loliumperenne was not only common among the allergy patients but remained consistently high over a period of ten months. The HDMs: Dermatophagodies farinae and Dermatophagodies pteronyssinus are common sensitizing allergens (8) and have been implicated in the induction of airway hperresponsiveness (12). HDM skin prick reactivity has been shown to exhibit seasonal variation with highest incidence in winters compare to summer season (13). Whereas HDMs have been frequently reported as common allergens in airway allergy cat allergen reactivity was found to be higher than HDM allergen reactivity in the present study. Cat allergen exposure is believed to be involved in $29 \%$ of asthma cases in the United States of America where $17 \%$ of the population is estimated to be sensitized to cat allergens (14). Cat is a popular pet all over the Kingdom of Saudi Arabia and could possibly be related to over 50\% cat allergen sensitization observed in the present study.Seasonal variation in skin test reactivity to cat allergen has been reported with less frequent occurrence during summer time (15). However, the reactivity to cat allergen remained high for almost ten months in the present study both in winters and in summers. The climate of the Kingdom of Saudi Arabia is predominantly hot and seasonal variations are infrequent that may explain persistently elevated skin prick reactivity to cat and HDM allergens observed in the present study.

Among the outdoor allergens Salsola kali, Cynodon dactylon, Lolium perenne and Amaranthus retroflexus were the most frequently reacting allergens and skin prick test reactivity was observed to be persistently high during the winter and summer seasons. Seasonal variations of pollens have been implicated in induction signs and symptoms of allergy during pollinating seasons among sensitized individuals (16). There is however some evidence suggesting that there is a time lag between high pollen counts and allergen levels (17) that could possibly explain the variations between the pollen counts and symptom scores for grasses and birch pollen (18). Presence of highly allergenic pauci-submicronic particles have been implicated in the lack of correlation between allergic symptoms and pollen counts. These particles are not only present during the pollinating seasons but are also present outside the pollen season resulting in persistent skin prick reactivity observed in the present study (19). The hot desert environment along with less than $10 \mathrm{~mm}$ annual rainfall and possible presence of pauci-submicronic particles particularly in Riyadh region may be important contributing factors in persistent exposure of local population to aeroallergens. The pattern of skin test reactivity observed in the present study supports high ambient pollen load throughout the year. 
Seasonal variations are influenced by the climate change and have direct bearing on allergic disorders (20). Changes in the environmental temperature influence the growth of Lolium perenne with stunting of its growth at low soil temperature (21). The effects of seasonal change have been demonstrated by reloacting Lolium perenne from cooler to a warmer location with induction of growth spurt (22). Moreover, high ambient temperature has also been implicated not only in increased environmental pollen counts (23) but has also been shown to have a significant contribution in enhancing the allergenicity of the pollens (24). An increase of $1 \mathrm{oC}$ in the temperature has been shown to result in a $14 \%$ increase in the number of patients seeking medical assistance (25). Additionally, high environmental temperature is also known for its association with early start and prolongation of pollen season (26). The persistently high skin test reactivity to common allergens in Riyadh region with average temperature of $45 \mathrm{oC}$ with extended summer time could possibly be due to presence of high allergen exposure lacking seasonal variations.

Aerobiological studies assessing the environmental allergen load in the local environment may provide valuable information for better understanding the interplay between the allergen load and sensitization status of the local population. An optimum allergen exposure over a prolonged period of time is essential for induction of allergy symptoms as high dose of allergen exposure has been shown to be capable of inducing tolerance (27).

In conclusion, based on the skin prick test reactivity it was observed that reactivity to aeroallergen was high in Riyadh region. The pattern of reactivity against both the indoor and outdoor allergen was devoid of seasonal variation and was persistently high during the year. This was a single center study from Riyadh region and the findings of the present study may not be applicable to the Kingdom of Saudi Arabia. Large scale studies across the Kingdom are recommended to assess the seasonal variations of aeroallergens and their impact on the local population.

\section{Referecnes:-}

1. Abbas AK, Lichtman AH, Pober JS. Cellular and molecular immunology. 2nd ed. Philadelphia, PA: WB Saunders; 1994.

2. Henderson LL, Larson JB, Gleich GJ. Maximal rise in IgE antibody following ragweed pollination season. J Allergy ClinImmunol 1975; 55:10-5.

3. Sin BA1, Inceoglu O, Mungan D, Celik G, Kaplan A, Misirligil Z. Is it important to perform pollen skin prick tests in the season? Ann Allergy Asthma Immunol. 2001;86(4):382-6.

4. Ginis T, Bostanci I, Ozmen S, Misirlioglu ED, Dogru M, Duman H. Subjective and objective assessments of seasonal effect in children with seasonal allergic rhinitis. Int J Pediatr Otorhinolaryngol. 2015;79(3):405-10. doi: 10.1016/j.ijporl.2014.12.038. Epub 2015 Jan 7.

5. Baibergenova A, Thabane L, Akhtar-Danesh N, et al. Effect of gender, age, and severity of asthma attack on patterns of emergency department visits due to asthma by month and day of the week. Eur J Epidemiol 2005; 20: 947-956.

6. Ghosal K1, Pandey N2, Bhattacharya SG1. Biomonitoring of pollen grains of a river bank suburban city, Konnagar, Calcutta, India, and its link and impact on local people. Ann Agric Environ Med. 2015;22(2):236-42. doi: 10.5604/12321966.1152072.

7. Holgate ST, Lemanske RF Jr, O'Byrne PM, Kakumanu S, Busse WW. Asthma pathogenesis. In: Adkinson NF Jr, Bochner BS, Busse WW, Holgate ST, Lemanske RF Jr, Simons FER, editors. Middleton's al $\neg$ lergy: principles \& practice. 7th ed. Philadelphia: Mosby; 2009. 893-919.

8. Han ER, Choi IS, Lee S, Cho YW. Airway hyperresponsiveness-related aeroallergens in suspected asthma. Korean J Asthma Allergy Clin Immunol 2007;27:105-10.

9. Kim JH, Choi SY, Lee IY, Lee YW, Yong TS, Kim CW, Song YS, Park JW, Kim YS, Park JW, Hong CS. Seasonal variation of house dust mite and its influence on the inhabitant health. Korean J Asthma Allergy Clin Immunol 2006;26:27-34.

10. Kim E, Kim MJ, Lee JS, Yoon JS. Association between autumnal exacerbation and Dermatophagoides pteronyssinus specific IgE in childhood asthma. Pediatr Allergy Respir Dis 2007;17:242-8.

11. Gergen PJ, Turkeltaub PC. The association of individual allergen reactivity with respiratory disease in a national sample:data from the Second National Health and Nutrition Examination Survey, 1976-80 (NHANES II). J Allergy Clin Immunol 1992;90:579-88.

12. Choi IS, Koh YI, Koh JS, Lee MG. Sensitivity of the skin prick test and specificity of the serum-specific IgE test for airway responsiveness to house dust mites in asthma. J Asthma 2005;42:197-202.

13. Choi IS, Ki WJ, Kim TO, Han ER, Seo IK. Seasonal factors influencing exercise-induced asthma. Allergy Asthma Immunol Res. 2012;4(4):192-8. doi: 10.4168/aair.2012.4.4.192. Epub 2012 Feb 24. 
14. Arbes SJ Jr, Gergen PJ, Elliott L, Zeldin DC. Prevalences of positive skin test responses to 10 common allergens in the US population: results from the third National Health and Nutrition Examination Survey. J Allergy ClinImmunol 2005; 116:377-83.

15. Choi IS, Lee SS, Myeong E, Lee JW, Kim WJ, Jin J. Seasonal variation in skin sensitivity to aeroallergens. Allergy Asthma Immunol Res. 2013;5(5):301-8. doi: 10.4168/aair.2013.5.5.301. Epub 2013 Aug 7.

16. Canova C, Heinrich J, Anto JM, Leynaert B, Smith M, Kuenzli N et al. The influence of sensitisation to pollens and moulds on seasonal variations in asthma attacks. Eur Respir J. 2013;42(4):935-45. doi: 10.1183/09031936.00097412. Epub 2013 Mar 7.

17. Cabrera M, Martinez-Cocera C, Fernandez-Caldas E, Carnes Sanchez J, Boluda L, Tejada J, Subiza JL, Subiza J, Jerez M. Trisetum paniceum (wild oats) pollen counts and aeroallergens in the ambient air of Madrid, Spain. Int Arch Allergy Immunol 2002;128(2):123-9.

18. Johnsen CR, Weeke ER, Nielsen J, Jensen J, Mosbech H, Frolund L, Madsen F, Poulsen LK. Aeroallergen analyses and their clinical relevance. II. Sampling by high-volume airsampler with immunochemical quantification versus Burkard pollen trap sampling with morphologic quantification. Allergy 1992;47(5):510-6.

19. D'Amato G. Airbone paucimicronic allergen-carrying particles and seasonal respiratory allergy. Allergy 2001; 56:1109-1111.

20. Beggs PJ: Impacts of climate change on aeroallergens: past and future. Clin Exp Allergy 2004, 34:1507-1513.

21. Hurtado-Uria C, Hennessy D, Shalloo L,O'Connor,D, DelabyL. Relationships between meteorological data and grass growth over time in the south of Ireland. Ir. Geogr. 2013;46, 175-201.doi:10.1080/00750778.2013. 865364

22. Davies A, Evans ME, Pollock, CJ. Influence of date of tiller origin on leaf extension rates in perennial and Italian rye grass at $15 \mathrm{oC}$ in relation to flowering propensity and carbohydrate status. Ann. Bot. 1989;63, 377384.

23. Frei T, Gassner E: Climate change and its impact on birch pollen quantities and the start of the pollen season an example from Switzerland for the period 1969-2006. Int J Biometeorol 2008;52:667-674.

24. Ahlholm JU, Helander ML, Savolainen J: Genetic and environmental factors affecting the allergenicity of birch (Betula pubescens ssp. czerepanovii [Orl.] Hämet-ahti) pollen. Clin Exp Allergy 1998;28:1384-1388.

25. Kim SH, Park HS, Jang JY. Impact of meteorological variation on hospital visits of patients with tree pollen allergy. BMC Public Health. 2011;24;11:890. doi: 10.1186/1471-2458-11-890.

26. Emberlin J, Detandt M, Gehrig R, Jaeger S, Nolard N, Rantio-Lehtimäki A: Responses in the start of Betula (birch) pollen seasons to recent changes in spring temperatures across Europe. Int J Biometeorol 2002, 46:159170 .

27. Woodfolk JA. High-dose allergen exposure leads to tolerance. Clin Rev Allergy Immunol 2005; 28:43-58. 